\title{
Spatial Analysis to Mitigate the Spread of Covid-19 Based on Regional Demographic Characteristics
}

\author{
Mochamad Firman Ghazali ${ }^{1,}$, Anggun Tridawati ${ }^{2}$, Mamad Sugandi ${ }^{1}$, Aqilla Fitdhea Anesta ${ }^{1}$, \\ Ketut Wikantika ${ }^{2,3}$ \\ ${ }^{1}$ Geodesy and Geomatics Engineering, Universitas Lampung, Jl. Prof. Dr. Ir. Sumantri Brojonegoro, \\ No: 1, Gedong Meneng, Kec. Rajabasa, Bandar Lampung, Lampung 35141 \\ ${ }^{2}$ Geodesy and Geomatics Engineering, Institut Teknologi Bandung \\ ${ }^{3}$ Remote Sensing and Geographic Information Science Expertise Group (INSIG), Institut Teknologi \\ Bandung \\ *) Corresponding Author: firman.ghazali@eng.unila.ac.id)
}

\begin{abstract}
COVID-19 is currently the hot topic of discussion by scientists because of its ability to quickly spread, in line with everyday human activities. One of the environmental factors related to climatic parameters, such as the air temperature, contributed to the spreading of COVID-19 in the last four months. Its distribution ability is no longer local as it successfully halts the important activities in many countries globally. This study aims to explain the opportunity of geospatial analysis in handling the COVID-19 distribution locally based on the characteristics of demographic data. Various data, including the confirmed positive for COVID-19, age-based population, and Landsat 8 satellite imagery data were used to determine the spatial characteristics of the COVID-19 distribution per September 2020 in Bandung, Indonesia. An inverse distance weighted (IDW), Moran's I index and local indicator spatial association (LISA), and a proposed ratio of the elderly population against the population with confirmed positive for COVID-19 (CoVE) were used as the approach to determine its distribution characteristics. The information derived from Landsat 8 satellite imagery, such as the residential area, surface temperature, and humidity based on the supervised classification, land surface temperature (LST), and the normalized difference water index (NDWI) was used to perform the analysis. The results showed that the positive population of COVID-19 was concentrated in Bandung city. However, with a Moran's I value of 0.316 , not all are grouped into the same category. There are only $8,2,5$, and 3 districts categorized as $\mathrm{HH}, \mathrm{HL}, \mathrm{LL}$, and LH. However, the areas with a large or small number of elderlies do not always correlate with the high number of confirmed positives for COVID-19. There are only 3, 1, and 3 districts classified as HH, HL, and LL. They were represented by the values of Moran's I, for about 0.057. The positive relationship between confirmed positive for COVID-19 and the built-up area, surface temperature, humidity, and the elderly population based on the coefficient of determination (R2) were $0.03,0.28,0.25$, and 0.019 , respectively. The study also shows that the vulnerability of those areas is relatively low. The study shows that the vulnerabilities in these areas are relatively low and the recommendation for COVID-19 widespread mitigation has to consider the demographic characteristics precisely in the large scale social restrictions (LSSR).
\end{abstract}

Keywords: COVID-19, inverse distance weighted, elderly population, spatial distribution, mitigation, Large-Scale Social Restrictions (LSSR)

\section{Introduction}

The pandemic occurs when disease spreads in a geographically large area. It is believed that it harms human life. Several viruses and bacteria, including Ebola,
HIV/AIDS, and cholera were successfully created this condition (Gayle \& Hill, 2001; Goeijenbier et al., 2014; Kaner \& Schaack, 2016; WHO, 2020)West Africa is facing the largest outbreak of Ebola virus disease 
(EVD. Many environmental characteristics are believed to be one of the contributing factors that accelerate the distribution of many diseases. As mentioned in Jutla et al. (2013), various factors such as heavy rainfall, inundation, sanitary infrastructure, and human interaction with contaminated water have massive contributions to cholera distribution. The socio-cultural factor also plays a similar role in the distribution of diseases. As reported by Gayle \& Hill (2001), in the United States the communities of color who are poor, undereducated, and have limited access to health services are increasingly at risk for HIV/ AIDS. Another factors like population growth and direct interaction with wildlife may have contributed to the spread of the Ebola virus (Alexander et al., 2015).

In the 2019 novel coronavirus disease (COVID-19) outbreak, some of the environmental conditions related to the socioeconomic factors, including population density, urban and rural settings, education level, and settlement density have given a different level of vulnerability (Saadat et al., 2020). The climatic variation, such as temperature and relative humidity, are often used to explain the influences of COVID-19 widespread (Bherwani et al., 2020; Eslami \& Jalili, 2020). The spatial pattern of COVID-19 is likely to follow the geographical characteristics that provide a different distribution pattern, so called cluster or non-cluster. For example, the occurrence of COVID-19 distribution in the Italian province seems to follow the topography and elevation characteristics. It shows thatthe highest cases occur in the northern part of the area and gradually decrease to the southern part (Martellucci et al., 2020). The pattern is similar to the global distribution of COVID-19 reported by Shariati et al. (2020), after the epicenter in Wuhan, China (Kang et al., 2020). At least there are still several countries in the Pacific and most of the African countries reported as free of COVID-19 confirmed cases per September 2020.

Furthermore, the study conducted by Xie et al. (2020) explains that the spread of COVID-19 according to the total of the confirmed cases is enhanced by the average air temperature and socio-economic conditions. The total of confirmed cases directly described the existence of COVID-19 in those areas. On the other hand, the places without the confirmed cases can define as the safest and un-vulnerable of the COVID-19 exposure. The relationship of its widespread based on socio-economic and climatic variables (e.g. temperature factors) are the crucial ones. Moreover, the configuration on elevation, the urban and rural settlement setting, the composition on land-cover and land-use, the latitude, and seasonal change are useful to understand this outbreak geospatially.

Focusing on the temperature and other weather parameters is possible to obtain from the satellite data (Shah et al., 2013)hydrological and environmen- tal studies. However, high spatial distribution patterns of air temperature are not available from mete- orological stations due to its sparse network. The objective of this study was to estimate high spatial resolution minimum air temperature (Tmin. Several studies have been carried out using environmental parameters throughout this COVID-19 occurrence. These studies consider various parameters, such as weather and climate conditions (Bariotakis et al., 2020; Qi et al., 2020; Tosepu et al., 2020)pathogenic, SARS-CoV-2 causing the severe acute respiratory disease COVID-19, becomes a major health problem worldwide and pose the need for international predictive programs. Given the lack of both specific drugs and an efficient preventive vaccine, the expectation that SARS-CoV-2 transmission rate might decrease in temperate regions during summer, dominated the social scene. Here, we attempted a prediction of the worldwide spread of the infections based on climatic data, expressed by 19 bioclimatic variables. The calculated probability maps shown that potential areas of infection follow a shift from the Tropical to Temperate and Mediterranean Bioclimatic regions, and back to the Tropics again. Maps show an increased probability of infections in Europe, followed 
by an expansion covering areas of the Middle East and Northern Africa, as well as Eastern coastal areas of North America, South-Eastern coastal areas of Latin America and two areas of Southern Australia, and later return to areas of Southeastern Asia, in a manner similar to that of influenza strains (H3N2, the demographics factors (Ahmadi et al., 2020; Coccia, 2020), and the combination of these two parameters combined with geographic location (Luo et al., 2020). However, these studies do not directly explain its occurrence that threatens human life (Dennis et al., 2005).

Other geospatial data, e.g. satellite images, is used to provide a different perspective. This data is used to observe the relationship between health issues and environmental quality (Seltenrich, 2014). Understanding the spread of diseases based on their spatial patterns, some critical environmental factors, socio-cultural conditions, including human activities are very effective. Franch-Pardo et al. (2020) explains that these factors clearly enhance the mitigation capability.

Apart from the contribution of atmospheric conditions to the distribution of COVID-19 (Lewis, 2020; Van Doremalen et al., 2020), demographic aspects have yet to be discussed in more detail from the previous studies. The demographic structure in the form of population composition based on age is possible to use as the input parameter to determine the distribution of COVID-19. In the narrower scope, this study analyzes the relationships between demographic structure and the numbers of confirmed COVID-19 cases in the city and regency level. The analysis is also combined with several derived environmental parameters from satellite image data including humidity and surface temperature.

Geographic information system (GIS) based spatial analysis is the key to analyze the distribution of COVID-19. In the health sector, the spatial analysis is carried out using various methods, including spatial interpolation (DHS Spatial Interpolation Working Group, 2014; Meng et al., 2010), the spatial auto-correlation
(Zhang et al., 2019), and the overlapping of various parameters, such as the number of confirmed cases, population density, and regional status (Roy et al., 2020). In one condition, large-scale social restriction (LSSR) policies have been implemented in many regions in Indonesia. This policy is made by considering the number of people affected by COVID-19. For example, in Jakarta, Indonesia, the second large-scale social restriction (LSSR) was confirmed by authorities when the COVID-19 cases reached 49,837 or nearly a quarter of the country's official tally of 203,342 cases. In the West Java region, after confirmed 641 cases, this region becomes the second-largest COVID-19 cases (Dipa, 2020; Fachriansyah, 2020). It was only considered due to the increased vulnerability value of the COVID-19 positive cases to be concerning. The urgency of regional characteristics and demographics has yet to be considered in the handling of COVID-19 in Indonesia. The opportunity of geospatial analysis based on demographical characteristics must be explored further. This study aims to explain the opportunity of geospatial analysis in handling the COVID-19 distribution in a local area. The integration of data, including the confirmed positive for COVID-19, the aging structure of the population, and Landsat 8 satellite imagery are used to determine its characteristics.

\section{Research Method}

\subsection{Study location}

Two locations in Bandung region (Figure 1), called Bandung City and Bandung Regency, were selected based on the consideration of the large-scale social restrictions (LSSR) policy implementation. Bandung City has 30 districts with 151 sub-districts, 2,404,589 inhabitants and covers an area of $167.67 \mathrm{~km}^{2}$ (BPS Kota Bandung, 2020). It is relatively small compared to Bandung Regency. Bandung Regency covers the area of 1,762.39 km2, 31 districts with 270 sub-districts and 3,522,724 inhabitants (BPS Kabupaten Bandung, 2019). 

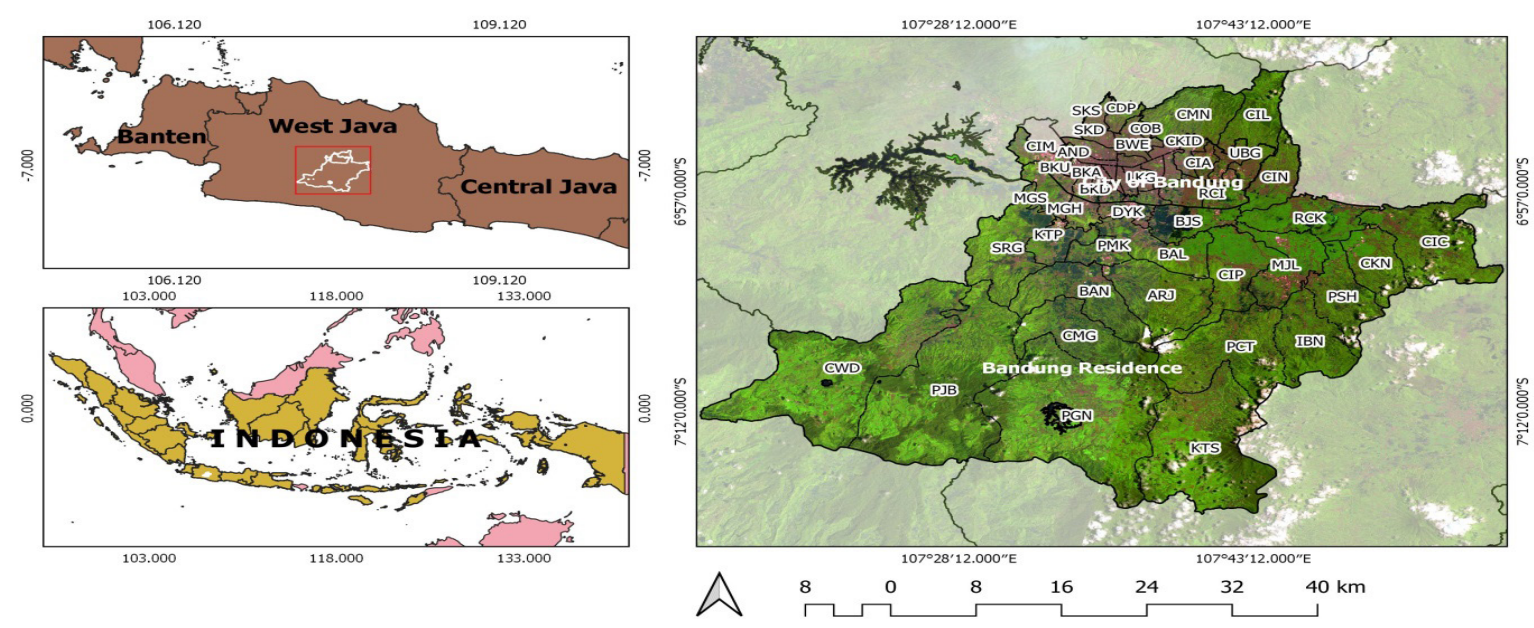

Figure 1. Study location for the distribution of COVID-19 in the Bandung region overlayed with a false-color composite of Landsat data image. The color represents different land-use (left figure) where green, brown, dark blue indicate the vegetated area, settlement and water, respectively.

Bandung City has implemented the LSSR policy, while Bandung regency has not. As documented from a local daily newspaper in the beginning of the pandemic, the government of Bandung City has implemented this policy twice. Bandung City and other regions in the Greater Bandung area have applied the LSSR from April 22nd to May 5th, 2020, and from May 6th to May 20th 2020 (Rizaldi, 2020). During these periods of time, the government of Bandung regency has yet to implement this policy (Mauludin, 2020). However, a few weeks later, the LSSR restriction has been applied to only five districts in that area (Handriansyah, 2020). In Indonesia, there are 33 provinces, where each province has several cities and regencies. Each city and regency have many districts and sub-districts that are also called villages in regency.

\subsection{Data}

There are two types of data used in this study. The first is the tabular data which consists of the confirmed case of COVID-19 positive patients and population data in two locations up to sub-district and village levels. Data of the confirmed positive for COVID-19 was obtained for free from the West Java Government official website (https://pikobar.jabarprov.go.id/) accessed on September 25th 2020. It shows the historical data from the early cases of COVID-19 in Bandung Region.

The population data is employed based on the aging structure, from the books published by the Central Statistics Agency (BPS), called "Kecamatan dalam Angka 2020" for all districts in Bandung Region. This data explicitly divides the population into different age groups, from 0 to $64+$ years old. The age population data is classified into the following categories: up to 15 years, 15 - 64 years and $65+$ years.

There are 61 books collected for age population data. Although the aging structure in Bandung City is available until the sub-districts as the lowest level, the similar data for the Bandung Regency is only available until the districts level. Formally they are different, however, the analysis is possible to equalize by summing up the elderly population in the sub-districts level within the same districts. Therefore, both data level between the Bandung City and Bandung Regency can be equal. Table 1 shows the highest confirmed COVID-19 cases and the elderly population. It shows that Cicendo and Mandalajati districts have the highest number of elderly populations. 
Table 1. Descriptive statistics of confirmed case of COVID -19 positive and elderly people.

\begin{tabular}{|c|c|c|c|c|c|}
\hline No & Statistic & & Summary & Districts & Location \\
\hline \multirow[t]{2}{*}{1} & \multirow[t]{2}{*}{ + COVID-19 } & Min & 1 & Majalaya & $\begin{array}{l}\text { Bandung } \\
\text { Regency }\end{array}$ \\
\hline & & Max & 47 & Cicendo & Bandung City \\
\hline \multirow{2}{*}{2} & \multirow{2}{*}{$\begin{array}{l}\text { Elderly } \\
\text { population }\end{array}$} & Min & 1462 & Cinambo & Bandung City \\
\hline & & $\operatorname{Max}$ & 29031 & Mandalajati & Bandung City \\
\hline
\end{tabular}

Source: processed from (BPS Kabupaten Bandung, 2020; BPS Kota Bandung, 2020; Pusat Informasi dan Koordinasi COVID-19 Jawa Barat, 2020)

Table 2. Landsat 8 data satellite image characteristics.

\begin{tabular}{cccccc}
\hline No & Path/Row & Band & Scene and Recorded time & $\begin{array}{c}\text { Spatial } \\
\text { Resolution }\end{array}$ & Purpose \\
\hline \multicolumn{1}{c}{$1122 / 65$} & $\begin{array}{c}\text { Green, Red, } \\
\text { Near-infrared, } \\
\text { Shortwave } \\
\text { infrared, and } \\
\text { thermal }\end{array}$ & $\begin{array}{c}\text { LC81220652020257LGN00 } \\
\text { September 13 }\end{array}$ & $\begin{array}{c}\text { 30, 30, 30, 30, } \\
\text { and 30* }\end{array}$ & $\begin{array}{c}\text { NDWI, LST, and } \\
\text { Supervised classification }\end{array}$ \\
\hline
\end{tabular}

*resampled to 30 from 100 meters.

\subsection{Data processing}

The confirmed COVID-19 cases data is necessary and corresponds with the aging structure data of respective districts in the study areas. These two data are used as the main attributes. The number of elderly, adult, young population, and the ratio between confirmed positive COVID-19 against the number of elderly are the important factors for the analysis in this study. All the attributes stored in vector data of administrative boundaries of the Bandung region are used as the inputs of the interpolated maps, including the positive-confirmed distribution and the ratio of the elderly population to the confirmed case of COVID-19 positive population (CoVE).

Additionally, this research introduces a new parameter, namely, CoVE. Once the equalizing procedure of the aging structure is applied, the CoVE can be obtained. To compute this ratio, the total population of confirmed case of COVID-19 positive $\left(\sum C\right)$ and the total elderly (> 65 years) population $\left(\sum \mathrm{E}\right)$ are required (Eq. 1). This formula is utilized as the confirmed case of COVID-19 positive is available in both districts and sub-districts level and has different structures compared to the aging population data provided by the Central Statistics Agency (BPS). As mentioned before, the aging population data at the sub-district level are only available for Bandung City and at the district level in Bandung Regency.

CoVE $=\frac{\sum C}{\sum E} \times 100$

The confirmed case of COVID-19 positive collected data is proceed without presenting the geographic location of the individual patient. It produces some limitations of both data interpretation and its quality. The term of limitation is related to the confirmed COVID-19 cases stored in the more extensive spatial coverage. At the same time, the individual data is unable to be shared to the public. However, the interpolation methods are considerably able to minimize this limitation as the neighboring values (confirmed COVID-19) are related. This also can be explained by Tobler (1970) that everything is related to everything else, but nearby things are more related than distant things. This explanation means the areas with the confirmed case of COVID-19 positive is potentially influenced by the surrounding areas. Even though each district has it, the analysis is unable to locate the occurrence precisely, and triggers the failure of interpretation when it is used for the smaller area than district level. In other 
words, the average of a group is not always the representative of the individuals (Dark \& Bram, 2007; Portnov et al., 2007)ecological fallacy is an incorrect assumption about an individual based on aggregate data for a group. In the present study, the validity of this assumption was tested using both individual estimates of exposure to air pollution and aggregate data for 1,492 schoolchildren living in the in vicinity of a major coal-fired power station in the Hadera region of Israel. In 1996 and 1999, the children underwent subsequent pulmonary function tests (PFT.

A spatial interpolation based on the inverse distanceweighting(IDW) method isimplemented for both the confirmed case of COVID-19 positive and the elderly population. This method does not require statistical calculation as kriging needs. It is only deployed a distance within known values (Seyedmohammadi et al., 2016) conservation and their quality increase is needful with data existence in basis of situation, amount and distribution of water chemical factors for example; electrical conductivity (EC. The parameter used for computing an IDW needs known values (z) and the distance (d) (Eq. 2).

$$
I D W=\frac{\left(\frac{Z 1}{d 1}\right)+\left(\frac{Z 2}{d 2}\right)+\left(\frac{Z 3}{d 3}\right)}{\left(\frac{1}{d 1}\right)+\left(\frac{1}{d 2}\right)+\left(\frac{1}{d 3}\right)}
$$

The distribution of confirmed COVID-19 and the CoVE in Bandung Region is evaluated using the spatial autocorrelation based on the global Moran's I, and it is expanded using the local indicator spatial association (LISA). Both are exciting methods to offer a widely usage of application, that calculate the correlation of values in a space and put it into a cluster and noncluster to assess the spatial pattern of an object. Previously the global Moran's I is proposed by Moran (1950) and LISA is explained by Anselin (1995). Many studies are implemented both concepts to understand the health phenomena, such as analysis of hand, foot, and mouth disease distribution in Shantou (Zhang et al., 2019), community health development (Anuraga \& Sulistiyawan, 2017), and poverty in East Java province (Bekti, 2012).
The formula is utilized for global Moran's I computation which requires $\mathrm{w}, \mathrm{So}$, and $\mathrm{Zi}$, where $\mathrm{Zj}$ as weights, deviations from the mean, and the sums of all weights at row standardized weights, respectively (Geoda, 2020). This parameter is shown in the formula (Eq. 2). All the variables used for LISA in Eq. 2 is explained in the formula below (Eq. 3-7). At the time, the values of Moran's I is already well-known and has positive values to indicate the similarities of the high or low attribute values from the neighboring features. These conditions are used as the basis for the clustering, as well as when a negative value is obtained (ArcGIS, 2020).

$I=\frac{n}{S_{o}} \frac{\sum_{i=1}^{n} \sum_{j=1}^{n} w_{i, j Z_{i} Z_{j}}}{\sum_{i=1}^{n} Z_{i}^{2}}$

$S_{o}=\sum_{i=1}^{n} \sum_{j=1}^{n} w_{i, j}$

$Z_{I}=\frac{I-E[I]}{\sqrt{V}[I]}$

$E[I]=\frac{-1}{(n-1)}$

$V[I]=E\left[I^{2}\right]-E[I]^{2}$

The satellite data of Landsat 8 is necessary to conduct the pre-processing steps. This process involves two sequential processes including the radiometric and atmospheric corrections. Both steps aim to obtain a corrected value of the digital number $(\mathrm{DN})$ which is free from the atmospheric influence, and in the form of the bottom of atmospheric (BoA) reflectance. This satellite image is already corrected geometrically, and does not need to perform the geometric correction (U. S. Geological Survey, 2016). A dark object subtraction processed by (Chavez, 1988) is used to obtain the BoA reflectance. The corrected image of Landsat 8 is essential to improve the classification result (Lin et al., 2015). 


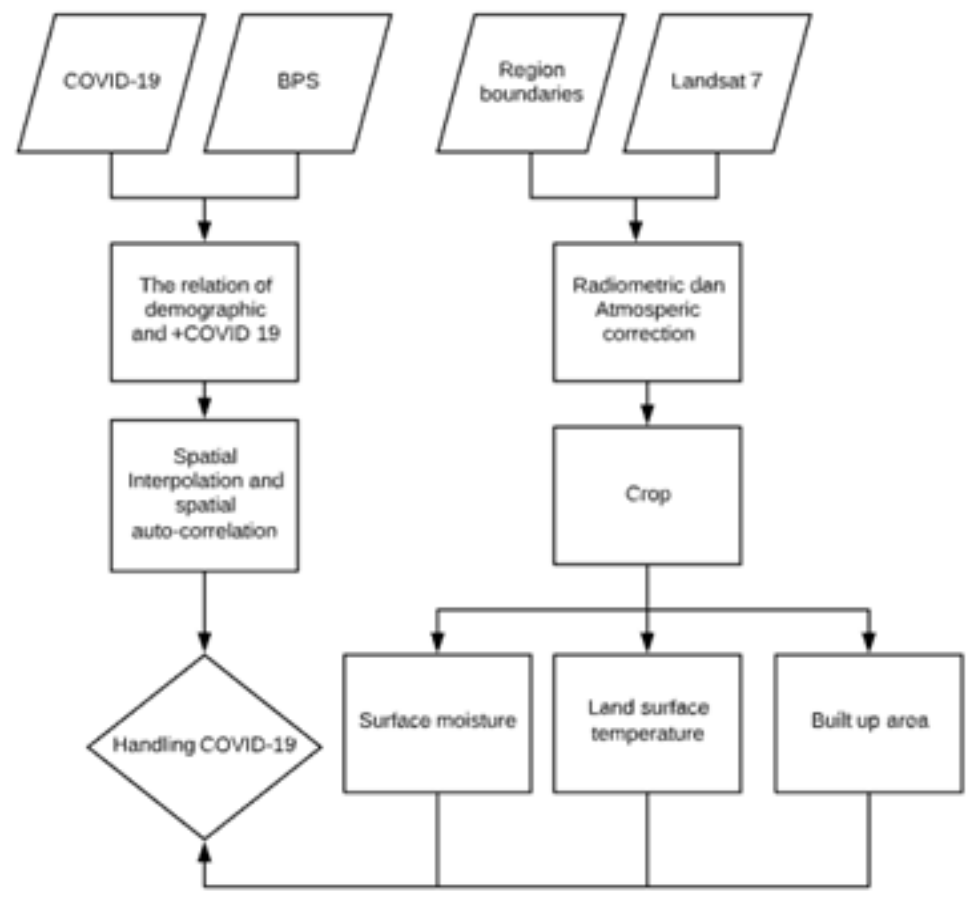

Figure 2. Research workflow.

Since the Landsat 8 is already corrected both radiometrically and atmospherically, it is then used to derive the surface moisture information based on the study conducted by McFeeters (2013). The ratio between the corrected green (B2) and near-infrared (B5) bands are employed to compute the normalized difference water index (NDWI) (Eq. 8). Besides that, the same formula by Sobrino et al. (2004) and Weng et al. (2004) is implemented to estimate the surface temperature (LST). Generally, the results depend on the quality of the thermal band (B10) (Eq. 9-11). Both results correspond with the distribution of residential area (built-up) that is obtained through a minimum distance method of supervised classification, with the overall accuracy and the kappa coefficient are $72 \%$ and 0.44 , respectively. The suggested range for the kappa coefficient group is moderate, for the result of minimum distance method (Richards, 2013). The LST is computed by three stages (Eq.14), including the digital numbers (DN) converting of the thermal band to radiance (Eq.9), computing the brightness temperature using the Planck Formula (Eq.10) and calculating the surface emissivity (Eq.11). From the normalized difference vegetation index (NDVI), proportion vegetation (Pv), the maximum and minimum values of NDVI are required to determine the $\mathrm{Pv}$ of -0.33 and 0.54, respectively (Eq. 12-13). The thermal band (band 10) of Landsat 8 converts into the spectral radiance before calculating the LST. The is the spectral radiance in watts/ $(\mathrm{m}-2$ srad-1 $\mu \mathrm{m}-1)$; is the band multiplicative rescaling factor; is the band-specific additive rescaling factor; is the DN values of band 10; is the brightness temperature in Celcius; $\mathrm{K} 1$ and K2 are thermal conversion constants which are taken from the metadata. For LST, is the wavelength of emitted radiance $(11.5 \mu \mathrm{m})$,, and is emissivity (Cartalis, 2019). The entire process is shown in the diagram below (Figure 2).

The results of the two stages are the visual analysis showing a correlation between the spatial autocorrelation of COVID-19 sufferers in the entire study area. Likewise, with satellite data analysis, there is a correlation between COVID-19, the demographic structure, and information derived from the Landsat 8 satellite image. Finally, they are all used to layout a recommendation for formulating an area that must implement the large-scale social restrictions (LSSR) policy. 


\section{Results and Discussion}

3.1 Spatial distribution of the confirmed case of COVID-19 positive

The total population positively confirmed COVID-19 from all areas in the entire study area ranges from 1 to 47 people in each district. The results of spatial interpolation using the IDW method show that the distribution of the population is the confirmed case of COVID-19 positive in all study areas (Figure 3). The map shows that the total of people confirmed positively of COVID-19 tends to decreases into the south, while it gradually increases to the north that closes to Bandung City.

The top seven areas with high confirmed positive COVID-19 populations are highlighted in the dark red color. These places are situated in the following districts: Cicendo (CIE), Bandung Kulon (BKU), Sukajadi (SKD), Buah Batu (BBT), and Lengkong (LKG), Coblong
(COB) and Bojong Soang (BJS). There are 47 cases in CIE, 36 cases in BKU, 34 cases in BBT and SKD, and 32 cases in BJS, COB and LKG. The cases are higher compared to Bandung Regency, where there is only one reported case (in MJL).

This condition causes the area of Greater Bandung (Both City and Bandung Regency) to be spatially segmented based on the population of the confirmed case of COVID-19 positive. The population can be categorized into three regions: low, medium, and high cases (Figure 3). The map is generated from the accumulation of the confirmed case of COVID-19 positive data from all sub-districts and districts, up to the district level where the lowest number is one and the highest number is 47 . The interpolated map uses this data to provide a better and detail information, rather than using the accumulation cases at the sub-district level.

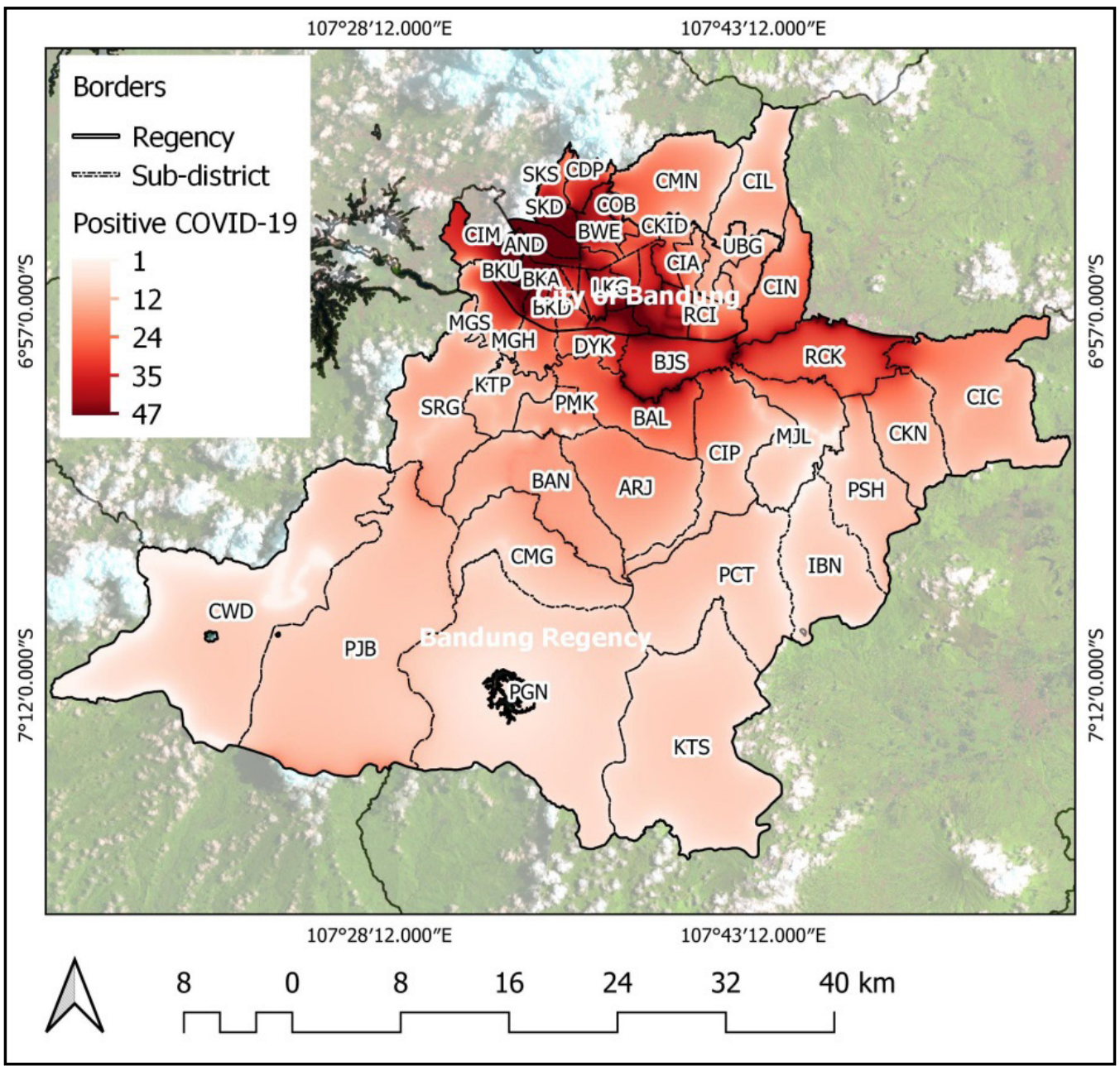

Figure 3. The distribution of the confirmed COVID-19 positive population. 


\subsection{Spatial distribution of CoVE}

The map of CoVE shows the ratio between the population the confirmed case of COVID-19 positive to the number of elderly (65+ years) based on the formula (1). The ratio ranges from 0.01 to 0.83 and the distribution is presented in the interpolation map (Figure 4). The maximum value of 0.83 on the map corresponds to the area with the highest COVID-19 cases of 32 people from 3855 elderly population which is in Bojong Soang (BJS) district. In general, the values of CoVE do not have a linear trend. On the other hand, the areas with the highest elderly population do not always have the highest COVID-19 cases, or vice versa. The interpretation has to follow the rules since the number of cases is relatively high. Even with the un-linear correlation between elderly population and COVID-19 cases in various districts and the number of the elderly population are similar, the area would become more vulnerable to the COVID-19. Apart of that factor, the vulnerable level is also influenced by the size of the district whose the CoVE values are more than 0.5, including Sumur Bandung (SMB), Buah Batu (BBT), Cibiru (CBR), Gedebage (GDB), Cicendo (CIE), and Bojong Soang (BJS).

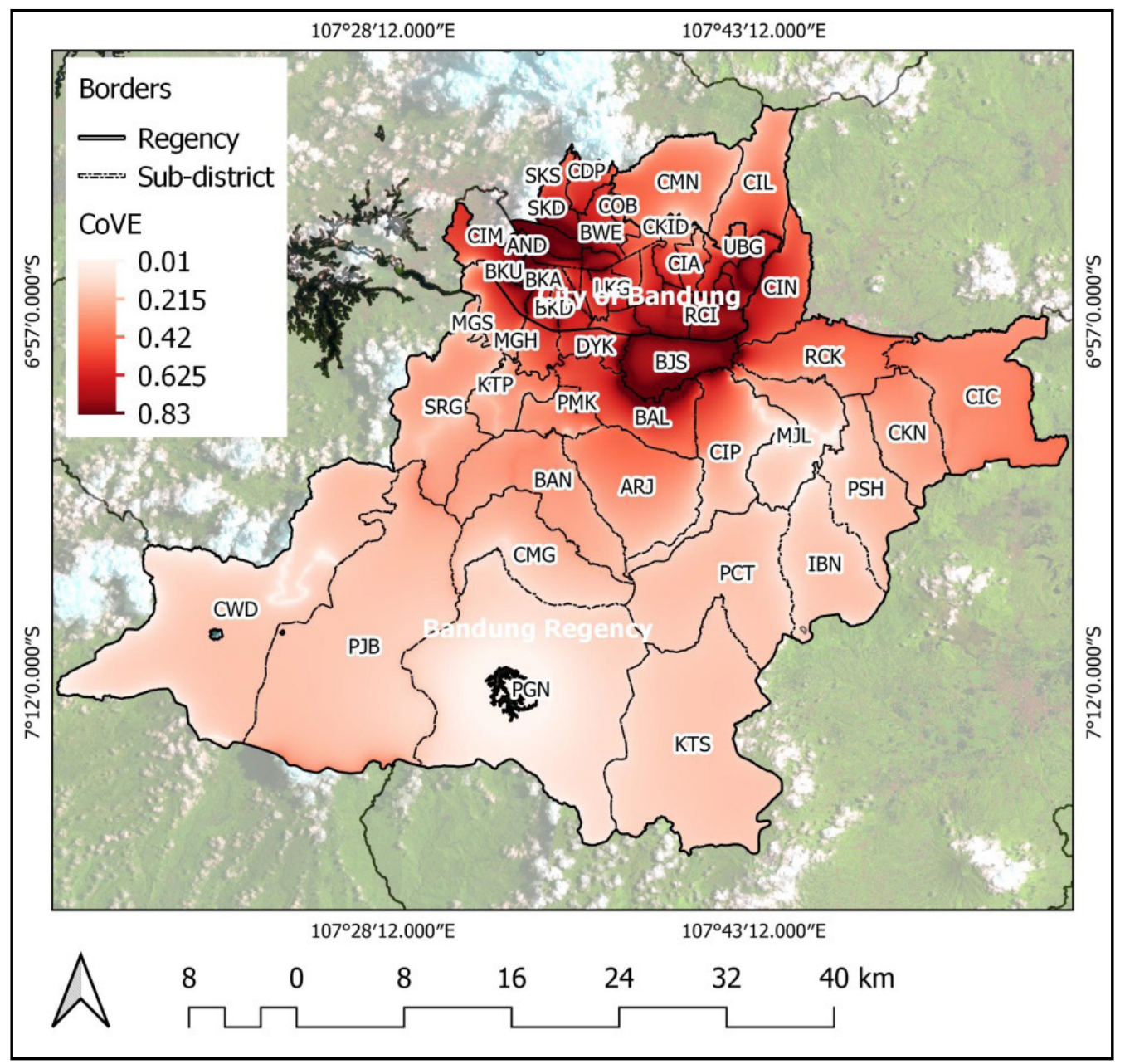

Figure 4. Distribution Map of the ratio of the old population to the positive population $(+)$ of COVID-19. 


\subsection{Spatial Autocorrelation of the confirmed case of COVID-19 positive and CoVE}

Statistically, the relationship between the positive $(+)$ population and the number of older people is nearly unrelated. The scatter diagram from the two data has a coefficient of determination (R2) of 0.00217. Spatially, a separate analysis is required by implementing the spatial autocorrelation approach. Based on the map of the local indicator spatial association (LISA), five regional clustered areas are obtained from the data on the number of positive population (+) COVID-19 (Figure $5)$. The eight districts are categorized as highhigh $(\mathrm{HH})$, two districts as high-low (HL), five districts as low-low (LL), and three districts as low-high (LH). In contrast, the remaining areas are categorized as not significant (NS) statistically. The eight regions with the $\mathrm{HH}$ are Sukajadi (SKD), Cicendo (CIE), Andir (AND), Sumur Bandung (SMB), Astana Anyar (AST), Regol (RGL), Bandung Kidul (BKI) and Buah Batu (BBT) districts. Meanwhile, those categorized as not significant (NS) occurred in areas with a low case of COVID-19. However, all these configurations are produced after the LISA analysis, where they indicate the trends of how the COVID-19 should be handled. There is no more large-scale social restrictions (LSSR) implementation. Local-scale social restrictions for several sub-districts in the south Bandung regency (Pasirjambu \& Margaasih, and Pacet \& Majalaya) are suggested to follow this scheme. However, a cluster of the COVID-19 distribution in the Bandung Region from the implementation of LISA is not clustered perfectly. The regional clustered conditions are illustrated by the scatter plot diagram of Moran's I of 0.316 (Figure 5a).

The eight districts that are clustered as $\mathrm{HH}$ are situated in Bandung City. One of the members is Cicendo (CIE) which has the highest confirmed COVID-19 cases. It is located between other districts, such as Sukajadi (SKD), Andir (AND), Sumur Bandung (SMB), Astana Anyar (AST), Regol (RGL), Bandung Kidul (BKI) and Buah Batu (BBT) where the cases are $34,29,15,16,17,31$, and 34 , respectively. This group is arranged based on the queen contiguity for weighted criteria. All the members do not always have the highest confirmed COVID-19 cases. Otherwise, the specific configuration has all the districts according to their relative positions to other regions. For example, the Sumur Bandung (SMB) has a lower case compared to other regions within this group. However, it is still higher compared to the other groups.

The ratio of the population of the confirmed case of COVID-19 positive to the total population of old age (65+ years) based on the local indicator spatial association (LISA) results four regional groupings (regional clustered) (Figure 5b). The study reveals the following classification: three districts are classified as high-high $(\mathrm{HH})$, one district as high-low (HL), and three districts as low-low (LL). The remaining areas are categorized as not statistically significant (NS). The three districts with the $\mathrm{HH}$ category are Cibeunying Kidul (CKID), Kiaracondong (KRC) and Antapani (ATP). Not significant (NS) is occurred in the low case area of COVID-19. The regional clustered condition is illustrated by the spread diagram of Moran's I of 0.057 (Figure 5b).

The previous study explains that the highest values of Moran's I are found in observing dynamic objects. For instance, the study by Santoso et al. (2019) reveals the increasing number in the manufacturing industries. The other study related to the health which correlated to the population number by Jackson et al. (2010) reveals the lowest value of Moran's I. Confirmed with other studies of the chemical compound in the soil, the Moran's I tends to give moderate to low values (Huo et al., 2012). The result from Moran's I of CoVE unveils the similar value with one by Jackson et al. (2010). Though both examples implement the phenomena with the less dynamic object such as human population. Finally, the Moran's I value of the confirmed case of COVID-19 positive is similar to the study from Santoso et al. (2019). This issue is a very dynamic object in the present time globally. 


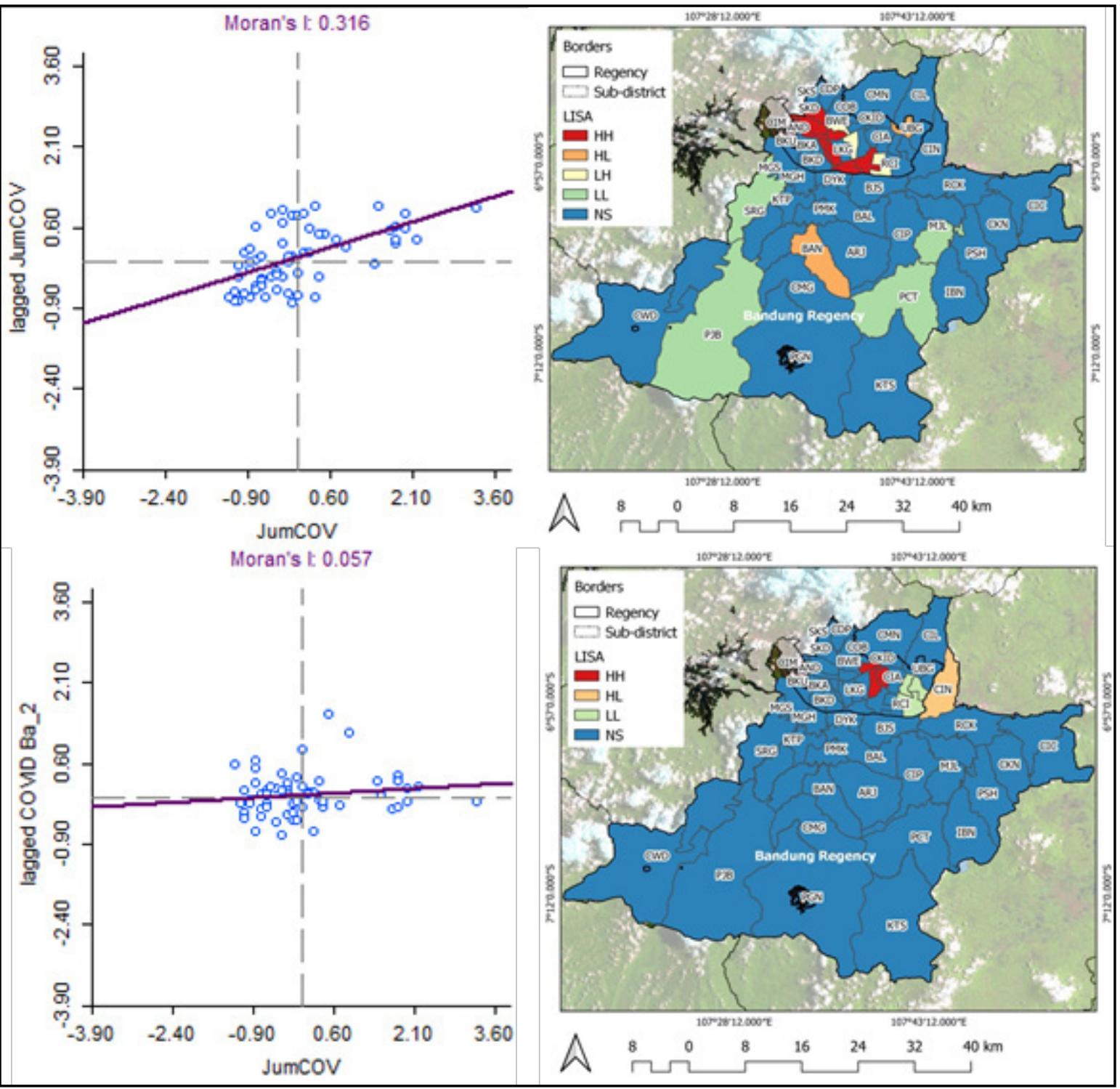

Figure 5. Map of distribution of the confirmed case of COVID-19 positive (above), and the CoVE ratio based on the Moran's I and LISA (bottom).

3.4 Environmental characteristics during the pandemic of COVID-19

The estimated values of NDWI and LST are resulted by the built-up areas derived from the minimum distance classification. The information of the covered the area is within the built-up region and the outside part of the built-up region is excluded from the analysis.

As a settlement area, the estimated values of the surface humidity in the entire study area range from -0.45 to 0.03 . These values indicate the lower capability of built-up areas in absorbing the water, unlike the vegetated and the bare soil areas. When the highest values are still lower, they are situated in the denser residential areas. These are typically occurred in the urban region like Bandung City. The estimated values of the surface temperature follow the same trend with the values of the surface humidity. The estimated values range from 20.2 to $32.6 \mathrm{OC}$ and correspond with the lowest and the dense residential areas (Figure 6).

The relation between the confirmed case of COVID-19 positive population to the environmental parameters including the builtup area (settlement), the surface temperature in the built-up area, surface humidity, and the elderly population are based on the coefficient of determination (R2) and give results of 0.03 , 
$0.28,0.25$ and 0.019 , respectively. The results of statistical calculations with this regression explain that the four experimental parameters positively correlate the distribution of COVID-19 in both locations in the Bandung region. This relationship describes its limitation based on the time observation on September 25th 2020.

Even though the correlation shows a weak category, the most exciting environmental parameters generate the highest values and are successfully established as new insights. Since both surface temperature and surface humidity in the built-up area are defined, they are still too early to utilize as the main parameters to build a proposed model for predicting the same situation in other places. Even though both surface temperature and surface humidity can change faster overtime, it is insufficient to illustrate the two factors to understand the distribution of COVID-19 in a small area. They are not supported by the competent statistical computation and expected to give the highest correlation determination (R2). The study results obtained by correlating information from the surface temperature extraction and surface humidity values are calculated based on the NDWI and LST formulas that are relatively large values, compared with two other parameters. These other parameters are the number of the elderly population and building area (settlement). These are also confirmed by the previous studies (Bariotakis et al., 2020; Qi et al., 2020; Tosepu et al., 2020; Xie et al., 2020) in which the same level of correlation is produced when it is applied to the small area like Bandung region. The distribution of surface temperature, surface humidity, and the built-up area, along with their environment values are presented on the maps (Figure 6) and the detailed values (Table 3).
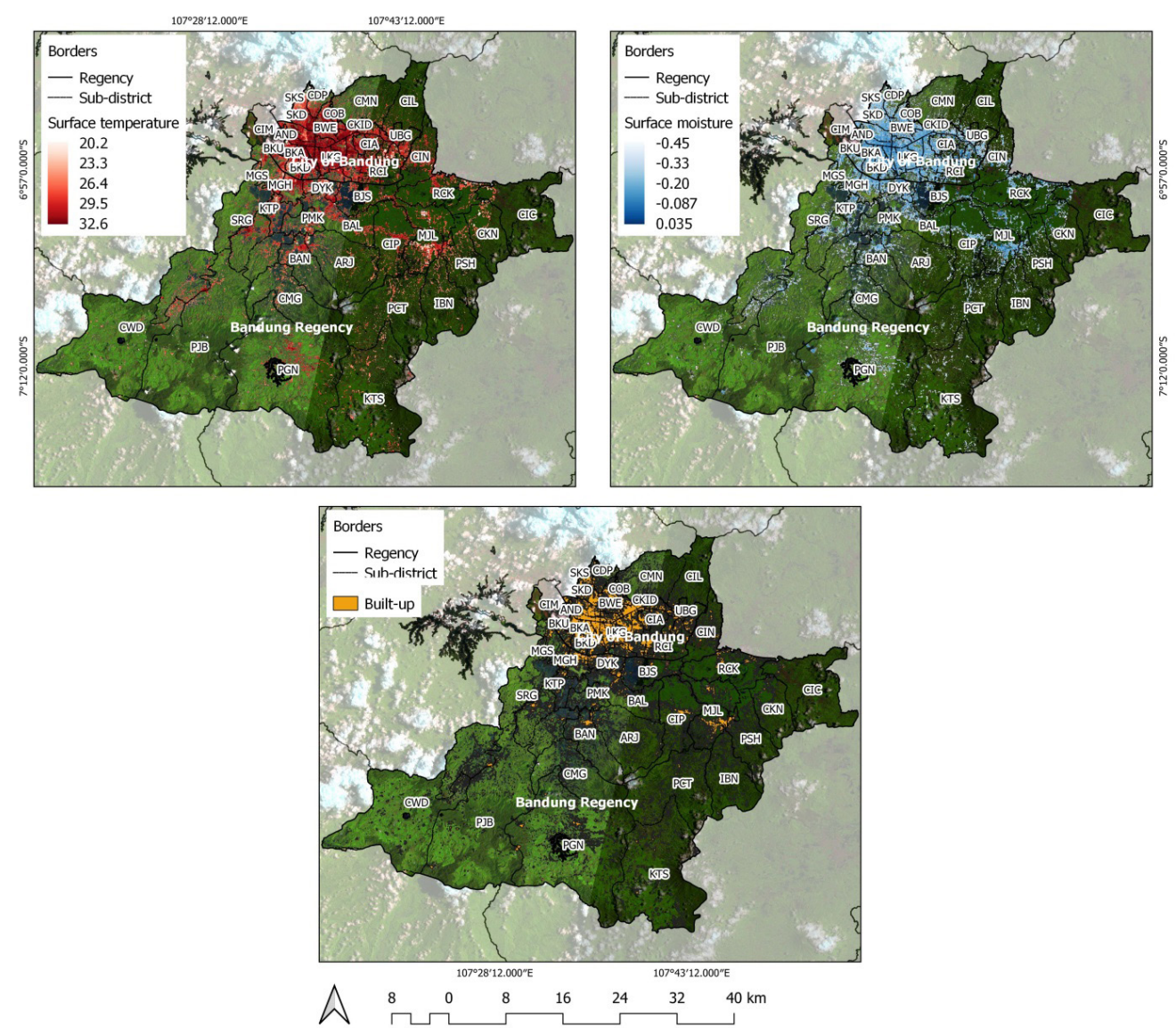

Figure 6. Distribution of residential areas (bottom), surface temperature (top left) and humidity (top right) as the result of supervised classification, LST, and NDWI. 
Table 3. Description of the residential area, surface temperature, and humidity, as well as the number of residents, the confirmed case of COVID-19 positive and the elderly population.

\begin{tabular}{ccccccc}
\hline No & District & $\begin{array}{c}\text { Area of } \\
\text { Settlement }\end{array}$ & $\begin{array}{c}\text { Average } \\
\text { Temperature } \\
\left({ }^{\circ} \mathbf{C}\right)\end{array}$ & $\begin{array}{c}\text { Average } \\
\text { humidity } \\
(\%)\end{array}$ & $\begin{array}{c}\text { Population } \\
+ \\
\text { COVID-19 }\end{array}$ & $\begin{array}{c}\text { Population } \\
\text { (65+ years } \\
\text { old) }\end{array}$ \\
\hline 1 & Andir & 385.676 & 30.72 & -0.17 & 29 & 7789 \\
10 & $\begin{array}{c}\text { Bandung } \\
\text { Wetan }\end{array}$ & 252.360 & 30.60 & -0.22 & 11 & 2892 \\
20 & Cibiru & 241.963 & 28.38 & -0.29 & 9 & 1583 \\
30 & Ciparay & 623.155 & 27.85 & -0.29 & 10 & 11117 \\
40 & Lengkong & 519.230 & 30.87 & -0.20 & 32 & 7089 \\
50 & Pasirjambu & 439.284 & 24.12 & -0.31 & 13 & 5739 \\
\hline
\end{tabular}

According to Table 3, several selected districts in the Bandung region shows the significant number of the confirmed case of COVID-19 positive when the estimated surface humidity values are low. The significant cases are also noticed in the area with higher surface temperature. Moreover, the number of older people within the area also contribute to the high cases of the COVID-19. The cases also have a linear correlation with the size of settlement areas, even with the less capacity based on the statistics.

\section{Conclusion}

Spatial analysis using spatial and nonspatial data integration provide another perspective in terms of the pattern and direction of the distribution of COVID-19. Demographic parameters have a lower correlation than the parameters of temperature, humidity, and residence area to the number of people the confirmed case of COVID-19 positive, including age and settlement size. Meanwhile, the application of spatial autocorrelation provides directions for handling the COVID-19 outbreak. The local government may consider to implement the spatial pattern obtained from LISA analysis. In this case, the application of large-scale social restrictions (LSSR) is more targeted and not divided based on the administrative boundaries but the spatial linkage instead. It would be useful to implement the partial scale social restrictions and consider the number of elderly people as the main variable. This is considered as they reside in some sub-districts where higher numbers of the confirmed case of COVID-19 positive are found. As the member of $\mathrm{HH}$ group, the Sukajadi (SKD), Cicendo (CIE), Andir (AND), Sumur Bandung (SMB), Astana Anyar (AST), Regol (RGL), Bandung Kidul (BKI) and Buah Batu (BBT) districts can be prioritized as the primarily targeted regions to minimize the harmful effect of the COVID-19 exposure. A similar method can also be applied to other groups. It requires the integration of each district where the existence of administrative boundaries is excluded. The application of spatial interpolation is likely the most straightforward step to determine the spatial trend of the COVID-19 outbreak distribution. In fact, the other distribution patterns are also crucial, including the other demographic parameters such as maternity, number of children, and mortality rate during the COVID-19 outbreaks. These parameters should be considered for further studies for a detailed analysis.

\section{References}

Ahmadi, M., Sharifi, A., Dorosti, S., Jafarzadeh Ghoushchi, S., \& Ghanbari, N. (2020). Investigation of effective climatology parameters on COVID-19 outbreak in Iran. Science of the Total 
Environment, 729. https://doi.org/10.1016/j.scitotenv.2020.138705

Alexander, K. A., Sanderson, C. E., Marathe, M., Lewis, B. L., Rivers, M., Shaman, J., Drake, J. M., Lofgren, E., Dato, V. M., Eisenberg, C., \& Eubank, S. (2015). What Factors Might Have Led to the Emergence of Ebola in West Africa? PLOS Neglected Tropical Diseases, 1-26. https:// doi.org/10.1371/journal.pntd.0003652

Anselin, L. (1995). Local Indicators of Spatial Association-LISA. Geographical Analysis Sumption, 27(2), 93-115. https://doi.org/10.1111/j.1538-4632.1995.tb00338.x

Anuraga, G., \& Sulistiyawan, E. (2017). Autokorelasi Spasial untuk Pemetaan Karakteristik Indeks Pembangunan Kesehatan Masyarakat (IPKM) Pada Kabupaten/Kota di Jawa Timur. Statistika, 5(2), 32-41.

ArcGIS. (2020). How Cluster and Outlier Analysis (Anselin Local Moran's I) works. ArcGIS Pro Documentation. $\quad$ https://pro.arcgis.com/en/pro-app/tool-reference/spatial-statistics/h-how-cluster-and-outlier-analysis-anselin-local-m.htm

Bariotakis, M., Sourvinos, G., Castanas, E., \& Pirintsos, S. (2020). Climatic influences on the worldwide spread of SARS-CoV-2. MedRXiv, 1, 0-2. https:// doi.org/10.1101/2020.03.19.20038158

Bekti, R. D. (2012). Pola Hubungan Kemiskinan Di Jawa Timur. ComTech, 3(1), 217-227.

Bherwani, H., Gupta, A., Anjum, S., Anshul, A., \& Kumar, R. (2020). Exploring dependence of COVID-19 on environmental factors and spread prediction in India. Npj Climate and Atmospheric Science, 38, 1-13. https:/ / doi.org/10.1038/s41612-020-00142-x

BPS Kabupaten Bandung. (2019). Kabupaten Bandung dalam angka 2019. BPS Kabupaten Bandung.

BPS Kabupaten Bandung. (2020). Kabupaten Bandung Dalam Angka 2020. In Penduduk dan Ketenagakerjaan (Vol. 2, Issue 1). BPS Kabupaten Bandung.

BPS Kota Bandung. (2020). Kota Bandung Dalam Angka 2020. BPS Kota Bandung.

Cartalis, C. (2019). Advanced Thermal Remote Sensing. 2019 Advanced International Training Course in Land Remote Sensing, 80.

Chavez, P. S. (1988). An improved dark-object subtraction technique for atmospheric scattering correction of multispectral data. Remote Sensing of Environment, 24(3), 459-479. https:/ / doi. org/10.1016/0034-4257(88)90019-3

Coccia, M. (2020). Factors determining the diffusion of COVID-19 and suggested strategy to prevent future accelerated viral infectivity similar to COVID. Science of the Total Environment, 729, 138474. https:/ / doi.org/10.1016/j.scitotenv.2020.138474

Dark, S. J., \& Bram, D. (2007). The modifiable areal unit problem (MAUP) in physical geography. Progress in Physical Geography, 31(5), 471-479. https:/ / doi.org/10.1177/0309133307083294

Dennis, R. A., Mayer, J., Applegate, G., Chokkalingam, U., Colfer, C. J. P., Kurniawan, I., Lachowski, H., Maus, P., Permana, R. P., Ruchiat, Y., Stolle, F., Suyanto, \& Tomich, T. P. (2005). Fire, people and pixels: Linking social science and remote sensing to understand underlying causes and impacts of fires in Indonesia. Human Ecology, 33(4), 465-504. https://doi. org/10.1007/s10745-005-5156-z

DHS Spatial Interpolation Working Group. (2014). Spatial Interpolation with Demographic and Health Survey Data : Key considerations (Issue September).

Dipa, A. (2020). COVID-19: Greater Bandung to impose large-scale social restrictions on Wednesday. The Jakarta Post. https://www.thejakartapost.com/news/2020/04/18/covid-19-greaterbandung-to-impose-large-scale-social-restrictions-on-wednesday.html 
Eslami, H., \& Jalili, M. (2020). The role of environmental factors to transmission of SARS - CoV - 2 ( COVID - 19). AMB Express, 10(92), 8. https:// doi.org/10.1186/s13568-020-01028-0

Fachriansyah, R. (2020). What you need to know about large-scale social restrictions in Jakarta. The Jakarta Post. https://www.thejakartapost.com/news/2020/04/08/jakarta-will-imposestronger-mobility-restrictions-on-friday-heres-what-you-need-to-know.html

Franch-Pardo, I., Napoletano, B. M., Rosete-Verges, F., \& Billa, L. (2020). Spatial analysis and GIS in the study of COVID-19. A review. Science of the Total Environment, 739, 140033. https:// doi.org/10.1016/j.scitotenv.2020.140033

Gayle, H. D., \& Hill, G. L. (2001). Global Impact of Human Immunodeficiency Virus and AIDS. Clinical Microbiology Reviews, 14(2), 327-335. https:/ / doi.org/10.1128/CMR.14.2.327

Geoda. (2020). Local Spatial Autocorrelation. An Introduction to Spatial Data Analysis. https:// geodacenter.github.io/workbook/6a_local_auto/lab6a.html

Goeijenbier, M., van Kampen, J. J. A., Reusken, C. B. E. M., Koopmans, M. P. G., \& van Gorp, E. C. M. (2014). Ebola virus disease: A review on epidemiology, symptoms, treatment and pathogenesis. Netherlands Journal of Medicine, 72(9), 442-448.

Handriansyah, H. (2020). PSBB di 5 Kecamatan Kabupaten Bandung Diperpanjang, Belajar dari Rumah Dilanjutkan hingga 13 Juli. Pikiran-Rakyat.Com. https://www.pikiran-rakyat.com/ bandung-raya/pr-01390964/psbb-di-5-kecamatan-kabupaten-bandung-diperpanjang-belajar-dari-rumah-dilanjutkan-hingga-13-juli

Huo, X., Li, H., Sun, D., Zhou, L., \& Li, B. (2012). Combining Geostatistics with Moran' s I Analysis for Mapping Soil Heavy Metals in Beijing , China. International Journal Research of Public Health, 9, 995-1017. https:// doi.org/10.3390/ijerph9030995

Jackson, M. C., Huang, L., Xie, Q., \& Tiwari, R. C. (2010). A modified version of Moran ' s I. International Journal of Health Geographic, 9(33), 1-10.

Jutla, A., Whitcombe, E., Hasan, N., Haley, B., Akanda, A., Huq, A., Alam, M., Sack, R. B., \& Colwell, R. (2013). Environmental Factors Influencing Epidemic Cholera. The American Society of Tropical Medicine and Hygiene, 89(3), 597-607. https:/ / doi.org/10.4269/ajtmh.12-0721

Kaner, J., \& Schaack, S. (2016). Understanding Ebola: The 2014 epidemic. In Globalization and Health (Vol. 12, Issue 1). BioMed Central Ltd. https:/ / doi.org/10.1186/s12992-016-0194-4

Kang, D., Choi, H., Kim, J. H., \& Choi, J. (2020). Spatial epidemic dynamics of the COVID-19 outbreak in China. International Journal of Infectious Diseases, 94, 96-102. https://doi. org/10.1016/j.ijid.2020.03.076

Lewis, T. (2020). How Coronavirus Spreads through the Air: What We Know So Far. Scientificamerican. https:/ / www.scientificamerican.com/article/how-coronavirus-spreads-through-theair-what-we-know-so-far1/

Lin, C., Wu, C.-C., Tsogt, K., Ouyang, Y.-C., \& Chang, C.-I. (2015). Effects of atmospheric correction and pansharpening on LULC classification accuracy using WorldView-2 imagery. Information Processing in Agriculture, 2(1), 25-36. https:/ / doi.org/10.1016/j.inpa.2015.01.003

Luo, W., Majumder, M., Liu, D., Poirier, C., Mandl, K., Lipsitch, M., \& Santillana, M. (2020). The role of absolute humidity on transmission rates of the COVID-19 outbreak. MedRXiv, 8. https://doi.org/10.1101/2020.02.12.20022467

Martellucci, C. A., Sah, R., Rabaan, A. A., Dhama, K., Casalone, C., Arteaga-Livias, K., Sawano, T., Ozaki, A., Bhandari, D., Higuchi, A., Kotera, Y., Fathah, Z., Roy, N., Ur Rahman, M. 
A., Tanimoto, T., \& Rodriguez-Morales, A. J. (2020). Changes in the spatial distribution of COVID-19 incidence in Italy using GIS-based maps. Annals of Clinical Microbiology and Antimicrobials, 19(1), 11. https:/ / doi.org/10.1186/s12941-020-00373-z

Mauludin, L. A. (2020). Pemkab Bandung Masih Mengkaji Opsi PSBB di Kabupaten Bandung. Tribun Jabar.Com. https://jabar.tribunnews.com/2020/04/12/pemkab-bandung-masih-mengkaji-opsi-psbb-di-kabupaten-bandung

McFeeters, S. K. (2013). Using the normalized difference water index (ndwi) within a geographic information system to detect swimming pools for mosquito abatement: A practical approach. Remote Sensing, 5(7), 3544-3561. https://doi.org/10.3390/rs5073544

Meng, G., Law, J., \& Thompson, M. E. (2010). Small-scale health-related indicator acquisition using secondary data spatial interpolation. International Journal of Health Geographics, 9, 1-17. https:/ / doi.org/10.1186/1476-072X-9-50

Moran, P. A. P. (1950). Notes on Continuous Stochastic Phenomena. Biometrika Trust, 37(1), 17-23.

Portnov, B. A., Dubnov, J., \& Barchana, M. (2007). On ecological fallacy, assessment errors stemming from misguided variable selection, and the effect of aggregation on the outcome of epidemiological study. Journal of Exposure Science and Environmental Epidemiology, 17(1), 106-121. https://doi.org/10.1038/sj.jes.7500533

Pusat Informasi dan Koordinasi COVID-19 Jawa Barat. (2020). Peta Kasus Covid-19. Pemerintah Provinsi Jawa Barat. https:/ / pikobar.jabarprov.go.id/

Qi, H., Xiao, S., Shi, R., Ward, M. P., Chen, Y., Tu, W., Su, Q., Wang, W., Wang, X., \& Zhang, Z. (2020). COVID-19 transmission in Mainland China is associated with temperature and humidity: A time-series analysis. Science of the Total Environment, 728, 6. https://doi. org/10.1016/j.scitotenv.2020.138778

Richards, J. A. (2013). Supervised Classification Techniques. In Remote Sensing Digital Image Analysis: An Introduction (pp. 247-494). Springer-Verlag Berlin Heidelber. https://doi. org/10.1007/978-3-642-30062-2

Rizaldi, B. A. (2020). Kota Bandung perpanjang PSBB hingga akhir Mei 2020. Antara News.Com. https:/ / www.antaranews.com/berita/1500892/kota-bandung-perpanjang-psbb-hingga-akhir-mei-2020

Roy, S., Bhunia, G. S., \& Shit, P. K. (2020). Spatial prediction of COVID-19 epidemic using ARIMA techniques in India. Modeling Earth Systems and Environment, 2019(0123456789). https:// doi.org/10.1007/s40808-020-00890-y

Saadat, S., Rawtani, D., \& Mustansar, C. (2020). Science of the Total Environment Environmental perspective of COVID-19. Science of the Total Environment, 728, 138870. https://doi. org/10.1016/j.scitotenv.2020.138870

Santoso, E., Ismail, M., Noor, I., \& Ekawaty, M. (2019). Geographical Pattern of Economic Activities : an Evidence from Large and Medium Manufacturing Industries in Indonesia. The 4rd International Conference in Planning in the 2019 Era of Uncertainty, 8. https://doi. org/10.1088/1755-1315/328/1/012038

Seltenrich, N. (2014). Remote-sensing applications for environmental health research. Environmental Health Perspectives, 122(10), A268-A275. https:/ / doi.org/10.1289/ehp.122-A268

Seyedmohammadi, J., Esmaeelnejad, L., \& Shabanpour, M. (2016). Spatial variation modeling of groundwater electrical conductivity using geostatistics and GIS. Modeling Earth Systems and 
Environment, 2(4), 1-10. https:/ / doi.org/10.1007/s40808-016-0226-3

Shah, D., Pandya, M., Trivedi, H. J., \& Jan, A. R. (2013). Estimating minimum and maximum air temperature using MODIS data over Indo-Gangetic Plain. Journal of Earth System Science, 122(6), 1593-1605. https:/ / doi.org/10.1007/s12040-013-0369-9

Shariati, M., Mesgari, T., Kasraee, M., \& Jahangiri-rad, M. (2020). Spatiotemporal analysis and hotspots detection of COVID-19 using geographic information system (March and April, 2020). Journal of Environmental Health Science and Engineering, 9. https://doi.org/10.1007/ s40201-020-00565-x

Sobrino, J. A., Jiménez-Muñoz, J. C., \& Paolini, L. (2004). Land surface temperature retrieval from LANDSAT TM 5. Remote Sensing of Environment, 90(4), 434-440. https://doi.org/10.1016/j. rse.2004.02.003

Tobler, W. R. (1970). A Computer Movie Simulating Urban Growth in the Detroit Region. Economic Geography, 46, 234-240.

Tosepu, R., Gunawan, J., Effendy, D. S., Ahmad, L. O. A. I., Lestari, H., Bahar, H., \& Asfian, P. (2020). Correlation between weather and Covid-19 pandemic in Jakarta, Indonesia. Science of the Total Environment, 725, 4. https:/ / doi.org/10.1016/j.scitotenv.2020.138436

U. S. Geological Survey. (2016). Conversion of DNs to physical units. In K. Zanter (Ed.), Landsat 8 (L8) data users handbook (2nd ed., pp. 60-61). Department of the Interior U.S. Geological Survey. https://doi.org/LSDS-1574

Van Doremalen, N., Bushmaker, T., Morris, D. H., Holbrook, M. G., Gamble, A., Williamson, B. N., Tamin, A., Harcourt, J. L., Thornburg, N. J., Gerber, S. I., Lloyd-Smith, J. O., De Wit, E., \& Munster, V. J. (2020). Aerosol and surface stability of SARS-CoV-2 as compared with SARS-CoV-1. In New England Journal of Medicine (Vol. 382, Issue 16, pp. 1564-1567). Massachussetts Medical Society. https:/ / doi.org/10.1056/NEJMc2004973

Weng, Q., Lu, D., \& Schubring, J. (2004). Estimation of land surface temperature-vegetation abundance relationship for urban heat island studies. Remote Sensing of Environment, 89(4), 467483. https:// doi.org/10.1016/j.rse.2003.11.005

WHO. (2020). Environmental risk factors. https://www.who.int/cholera/environmental_health/ en/

Xie, Z., Qin, Y., Li, Y., Shen, W., Zheng, Z., \& Liu, S. (2020). Spatial and temporal differentiation of COVID-19 epidemic spread in mainland China and its influencing factors. Science of the Total Environment, 744, 140929. https:/ / doi.org/10.1016/j.scitotenv.2020.140929

Zhang, H., Yang, L., Li, L., Xu, G., \& Zhang, X. (2019). The epidemic characteristics and spatial autocorrelation analysis of hand, foot and mouth disease from 2010 to 2015 in Shantou, Guangdong, China. BMC Public Health, 19(1), 998. https://doi.org/10.1186/s12889-0197329-5 